\title{
Erratum to: Medicines availability for non-communicable diseases: the case for standardized monitoring
}

\author{
Jane Robertson ${ }^{1,2^{*}}$, Cécile Macé ${ }^{\text {, Gilles Forte }}{ }^{1}$, Kees de Joncheere ${ }^{1}$ and David Beran ${ }^{3,4}$
}

\section{Erratum}

The copyright line was incorrect in the published manuscript.

The copyright line should be:

( 2015 World Health Organization; licensee BioMed Central.

This is an open access article distributed under the terms of the Creative Commons Attribution IGO License (http:// creativecommons.org/licenses/by/3.0/igo/legalcode), which permits unrestricted use, distribution, and reproduction in any medium, provided the original work is properly cited. In any reproduction of this article there should not be any suggestion that WHO or this article endorse any specific organisation or products. The use of the WHO logo is not permitted. This notice should be preserved along with the article's original URL.

The disclaimer for WHO authors and non-WHO authors should be:

The authors alone are responsible for the views expressed in this article and they do not necessarily represent the views, decisions or policies of the institutions with which they are affiliated.

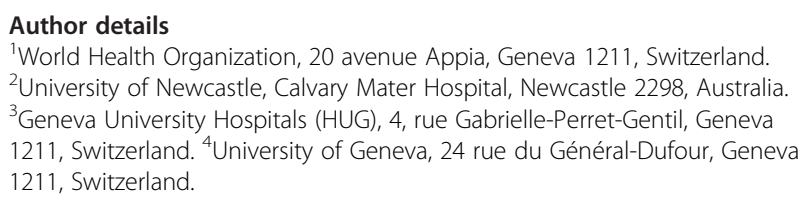

Published online: 06 August 2015

\footnotetext{
* Correspondence: ane.Robertson@newcastle.edu.au

${ }^{1}$ World Health Organization, 20 avenue Appia, Geneva 1211, Switzerland

${ }^{2}$ University of Newcastle, Calvary Mater Hospital, Newcastle 2298, Australia

Full list of author information is available at the end of the article

Submit your next manuscript to BioMed Central and take full advantage of:

- Convenient online submission

- Thorough peer review

- No space constraints or color figure charges

- Immediate publication on acceptance

- Inclusion in PubMed, CAS, Scopus and Google Scholar

- Research which is freely available for redistribution

Submit your manuscript at www.biomedcentral.com/submit 